\title{
Heterocyclic Trost's ligands. Synthesis and applications in asymmetric allylic alkylation
}

\author{
Denis Sinou, ${ }^{a}$ Nathalie Percina-Pichon, ${ }^{a}$ Angelica Konovets, ${ }^{b}$ and Alexander Iourtchenko ${ }^{b}$ \\ ${ }^{a}$ Laboratoire de Synthèse Asymétrique, associé au CNRS, CPE Lyon, Université Claude \\ Bernard Lyon 1, 43, boulevard du 11 novembre 1918, 69622 Villeurbanne Cédex, France \\ ${ }^{b}$ Institute of Organic Chemistry, National Academy of Sciences of Ukraine, Murmanskya Street \\ 5, 02094 Kiev 94, Ukraine \\ E-mail: sinou@univ-lyon1.fr
}

(received 16 Jul 04; accepted 22 Sept 04; published on the web 24 Sept 04)

\begin{abstract}
Condensation of $(1 R, 2 R)$-1,2-diaminocyclohexane with 2-(diphenylphosphino)nicotinic acid and 3-(diphenylphosphino)quinoxaline-2-carboxylic acid afforded the corresponding diphosphines. These ligands were used in the palladium-catalyzed alkylation of various allylic acetates with carbon and nitrogen nucleophiles, giving generally lower enantioselectivities than the analogous non-heterocyclic ligands.
\end{abstract}

Keywords: Heterocyclic chiral diphosphines, synthesis, asymmetric allylic alkylation

\section{Introduction}

Palladium-catalyzed asymmetric alkylation reaction is now a widely used process in organic chemistry, particularly for asymmetric carbon-carbon bond forming reaction. ${ }^{1-5}$ Although a variety of ligands has been found to achieve high level of enantioselectivity in this coupling reaction, the most important breakthrough was the synthesis and the use of Trost's ligand. Enantioselectivities higher than 95\% have been achieved using this ligand in carbon-carbon as well as carbon-nitrogen and carbon-oxygen bond formation. ${ }^{3}$ A variety of analogues containing anthracenyl, diphenyl, tartrate, or sugar-derived chiral scaffolds have been prepared in order to study the structural and electronic aspects of the ligand in different reactions. ${ }^{6-10}$ However to our knowledge there is no study concerning the preparation of such ligands containing an aromatic heterocycle instead of a phenyl ring. We present in this paper the preparation of two ligands 4 and 5, bearing an aromatic heterocycle, and give some preliminary results in the use of these ligands in asymmetric alkylation. 


\section{Results and Discussion}

2-(Diphenylphosphino)nicotinic acid (1) and 3-(diphenylphosphino)quinoxaline-2-carboxylic acid (2) were prepared by treatment of 2-chloronicotinic acid and 3-chloroquinoxaline-2carboxylic acid with $\mathrm{NaPPh}_{2}$ in liquid ammonia followed by acidification, in $64 \%$ and $38 \%$ chemical yield, respectively (Scheme 1).

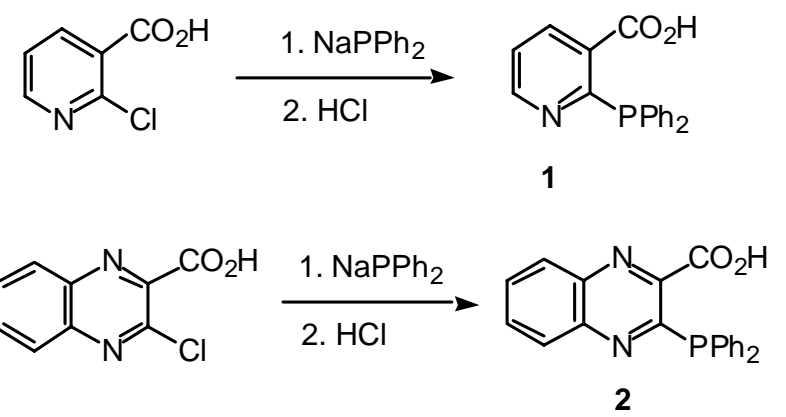

Scheme 1. Synthesis of diphenylphosphino acids.

The chiral ligands $\mathbf{4}$ and $\mathbf{5}$ were obtained according to Trost's methodology. ${ }^{6}$ The condensation of $(1 R, 2 R)$-1,2-diaminocyclohexane (3) with the corresponding phosphinocarboxylic acids 1 and $\mathbf{2}$ in THF at $\mathrm{rt}$ in the presence of DCC and a catalytic amount of DMAP gave the corresponding diphosphines $\mathbf{4}$ and 5 in $57 \%$ and $32 \%$ chemical yield, respectively, after purification by flash-chromatography (Scheme 2).<smiles>O=C(N[C@H]1CCCC[C@H]1NC(=O)c1cccnc1Pc1ccccc1)c1cccnc1P</smiles>

$(R, R)-4$

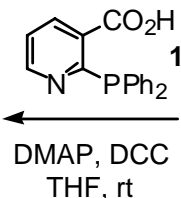

THF, rt<smiles>N[C@@H]1CCCC[C@H]1N</smiles>

$(1 R, 2 R)-3$

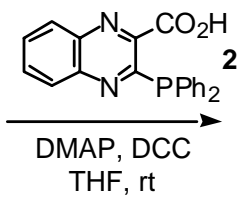

$(R, R)-5$

Scheme 2. Synthesis of heterocyclic diphosphines.

In order to investigate the ability of these new ligands in asymmetric catalysis and particularly in asymmetric alkylation, we performed some palladium-catalyzed reactions shown in Scheme 3. Preliminary results for reactions 1-3 are summarized in Table 1. 
The palladium-catalyzed alkylation of allylic acetates was carried out in the presence of a ( $\pi$ allyl)-palladium-ligand complex generated in situ from $2 \mathrm{~mol} \%\left[\mathrm{Pd}\left(\eta^{3}-\mathrm{C}_{3} \mathrm{H}_{5}\right) \mathrm{Cl}\right]_{2}$ and $8 \mathrm{~mol} \%$ of the appropriate chiral ligand. Alkylation of rac-1,3-diphenyl-2-propenyl acetate in THF as the solvent with the nucleophile generated from dimethyl malonate and $\mathrm{NaH}$ gave a quantitative transformation after $24 \mathrm{~h}$ using 4 as the chiral ligand (Table1, entry 1); however the observed enantioselectivity (24\%) was low. No improvement of this enantioselectivity was observed when the reaction was performed in $\mathrm{CH}_{2} \mathrm{Cl}_{2}$ as the solvent and in the presence of $\left(\mathrm{C}_{6} \mathrm{H}_{13}\right)_{4} \mathrm{NBr}^{11}$ in order to increase the solubility of the nucleophile (Table 1, entry 2). When 5 was used as the ligand, the reaction was sluggish (only $37 \%$ conversion after $24 \mathrm{~h}$ ), with no enantioselectivity (Table 1, entry 3 ).

Table 1. Some examples of palladium-catalyzed alkylation reactions ${ }^{\mathrm{a}}$

\begin{tabular}{|c|c|c|c|c|c|c|c|c|}
\hline Entry & Reaction & Nucleophile & Ligand & Solvant & Additif & Product & $\begin{array}{l}\text { Conv. } \\
(\%)^{b}\end{array}$ & $\begin{array}{l}\text { E.e. }(\%)^{b} \\
\text { (config) }^{\mathrm{b}}\end{array}$ \\
\hline 1 & 1 & $\mathrm{NaCH}\left(\mathrm{CO}_{2} \mathrm{CH}_{3}\right)_{2}$ & 4 & THF & no & $6 a$ & 100 & $24(S)$ \\
\hline 2 & 1 & $\mathrm{NaCH}\left(\mathrm{CO}_{2} \mathrm{CH}_{3}\right)_{2}$ & 4 & $\mathrm{CH}_{2} \mathrm{Cl}_{2}$ & THAB & $6 a$ & 100 & $19(S)$ \\
\hline 3 & 1 & $\mathrm{NaCH}\left(\mathrm{CO}_{2} \mathrm{CH}_{3}\right)_{2}$ & 5 & THF & no & $6 a$ & 37 & $3(R)$ \\
\hline 4 & 1 & $\mathrm{NaCH}\left(\mathrm{CO}_{2} \mathrm{CH}_{3}\right)_{2}$ & 4 & THF & no & $6 \mathbf{b}$ & 48 & $59(S)$ \\
\hline 5 & 1 & $\mathrm{NaCH}\left(\mathrm{CO}_{2} \mathrm{CH}_{3}\right)_{2}$ & 4 & THF & THAB & $6 b$ & 100 & $19(S)$ \\
\hline 6 & 2 & $\mathrm{NaCH}\left(\mathrm{CO}_{2} \mathrm{CH}_{3}\right)_{2}$ & 4 & THF & no & 7 & 98 & $18(S)$ \\
\hline 7 & 2 & $\mathrm{NaCH}\left(\mathrm{CO}_{2} \mathrm{CH}_{3}\right)_{2}$ & 4 & THF & THAB & 7 & 33 & $28(S)$ \\
\hline 8 & $2^{\mathrm{d}}$ & $\mathrm{NaCH}\left(\mathrm{CO}_{2} \mathrm{CH}_{3}\right)_{2}$ & 4 & $\mathrm{CH}_{2} \mathrm{Cl}_{2}$ & THAB & 7 & 100 & $19(S)$ \\
\hline $9^{\mathrm{e}}$ & 2 & $\mathrm{NaCH}\left(\mathrm{CO}_{2} \mathrm{CH}_{3}\right)_{2}$ & 4 & $\mathrm{CH}_{2} \mathrm{Cl}_{2}$ & THAB & 7 & 63 & $53(S)$ \\
\hline 10 & 2 & $\mathrm{NaCH}\left(\mathrm{CO}_{2} \mathrm{CH}_{3}\right)_{2}$ & 5 & THF & no & 7 & 18 & - \\
\hline 11 & 3 & & 4 & $\mathrm{CH}_{2} \mathrm{Cl}_{2}$ & THAB & 8 & 100 & $94(S)$ \\
\hline 12 & 3 & & 5 & $\mathrm{CH}_{2} \mathrm{Cl}_{2}$ & THAB & 8 & 100 & $8(S)$ \\
\hline
\end{tabular}

${ }^{a}$ [Allylic substrate]:[nucleophile]:[Pd]:[ligand] $=25: 75: 1: 2 ; 25^{\circ} \mathrm{C} ; 24 \mathrm{~h}$.

${ }^{\mathrm{b}}$ Determined by GC and HPLC analysis.

${ }^{\mathrm{c}}$ Determined by comparison of the rotation or the retention time with literature data.

${ }^{\mathrm{d}}$ The carbonate was used instead of the acetate.

${ }^{\mathrm{e}}$ Reaction carried out at $0{ }^{\circ} \mathrm{C}$.

Allylic alkylation of (2E)-1-propyl-2-hexen-1-yl acetate in THF using 4 as the ligand gave higher enantioselectivity (59\% ee), but lower conversion (48\%) (Table 1, entry 4); performing 
the reaction in $\mathrm{CH}_{2} \mathrm{Cl}_{2}$ in the presence of $\left(\mathrm{C}_{6} \mathrm{H}_{13}\right)_{4} \mathrm{NBr}^{11}$ gave a quantitative conversion in $\mathbf{6 b}$, but with lower ee (19\%) (Table 1, entry 5).

The condensation of cyclohexenyl acetate with the sodium salt of dimethyl malonate using 4 as the chiral ligand occured quantitatively in THF, the ee of compound 7 being 18\% (Table 1, entry 6). It is to be noted that when 5 was used as the ligand, the reaction was again very sluggish, only $18 \%$ conversion being observed after $24 \mathrm{~h}$ (Table 1, entry 10). Lower conversion was obtained when the alkylation reaction using $\mathbf{4}$ as the ligand was performed in THF in the presence of $\left(\mathrm{C}_{6} \mathrm{H}_{13}\right)_{4} \mathrm{NBr},{ }^{11}$ the enantioselectivity being $28 \%$ (Table 1, entry 7 ). However the use of $\mathrm{CH}_{2} \mathrm{Cl}_{2}$ as the solvent in the presence of $\left(\mathrm{C}_{6} \mathrm{H}_{13}\right)_{4} \mathrm{NBr}$ gave a quantitative conversion, with an enantioselectivity up to $19 \%$; when the reaction was performed at $0{ }^{\circ} \mathrm{C}$, the conversion was $63 \%$ and the enantioselectivity increased to $53 \%$ (Table 1 , entries 8-10).

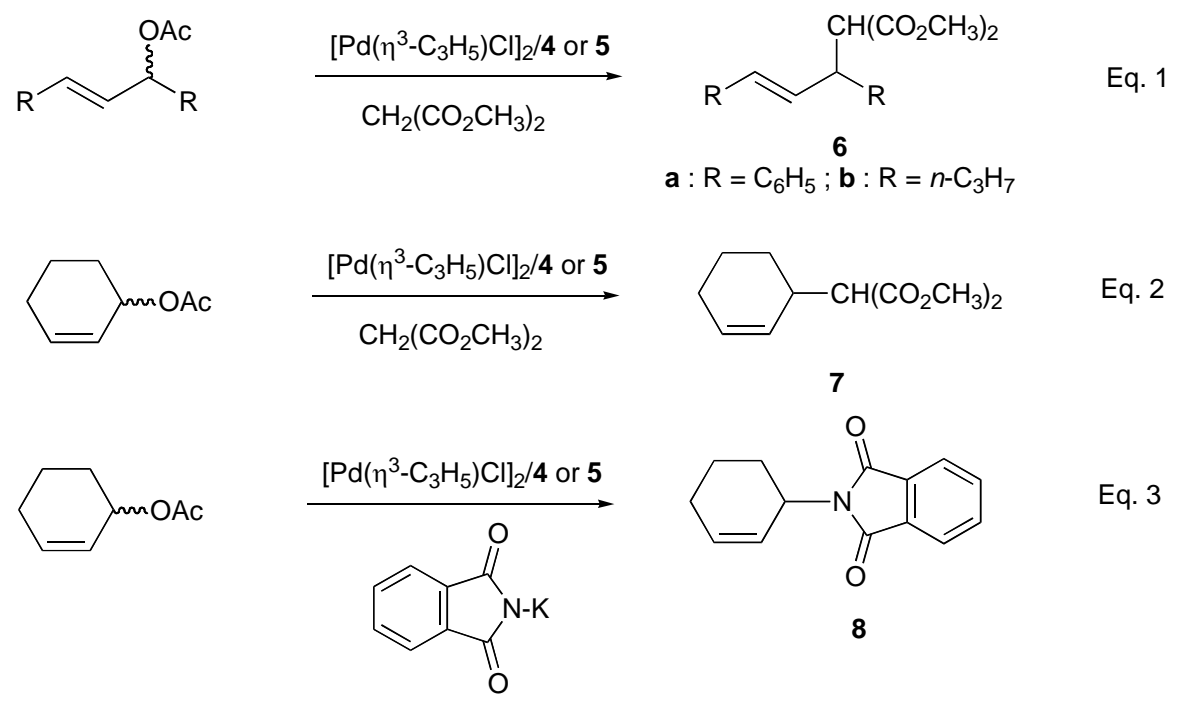

Scheme 3. Palladium-catalyzed alkylations.

Finally we used potassium phthalimide as a nitrogen nucleophile. Surprisingly when the reaction was carried out in $\mathrm{CH}_{2} \mathrm{Cl}_{2}$ in the presence of $\left(\mathrm{C}_{6} \mathrm{H}_{13}\right)_{4} \mathrm{NBr}$ using 4 as the ligand, the conversion to the corresponding amine 8 was quantitative, and the enantioselectivity was $94 \%$. (Table 1, entry 11) When 5 was used as the ligand, although the conversion was quantitative, the enantioselectivity of the coupling reaction was very low (only 8\%) (Table 1, entry 12).

These two new heterocyclic ligands gave ee lower than those observed using Trost's ligand, except when potassium phthalimide was used as the nucleophile. This lower enantioselectivity may be attributed to competition between the P-P (structure A), and the P-N (structure C), and eventually the P-O (structure B) chelation (Scheme 4). This rationale is also supported by the lower efficiency of ligand $\mathbf{5}$ vs $\mathbf{4}$ due to the higher number of possible P,N-chelations involved in. The P-O chelation in the case of Trost's ligand has been postulated by different groups. ${ }^{12-14}$ The dynamic isomerisation equilibrium between the $\mathrm{P}-\mathrm{O}$ and the $\mathrm{P}-\mathrm{N}$ chelation complexes has already been studied for the $\eta^{3}$-allyl nickel complex of methyl 2-(diphenylphosphino)benzoate. ${ }^{15}$ 
It is obvious that in the $\mathrm{P}-\mathrm{O}$ chelation, and moreover in the $\mathrm{P}-\mathrm{N}$ chelation complex, less efficient chiral environnement is effectively expected, since the chiral centers are remote from the $\pi$-allyl system.

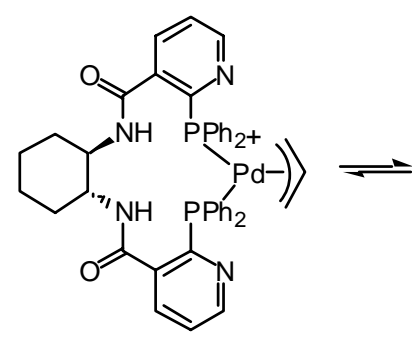

A

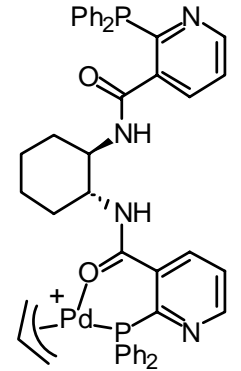

B

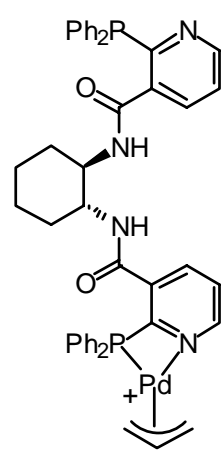

C

\section{Scheme 4}

In conclusion the heterocyclic Trost's ligands gave lower enantioselectivities in the palladium-catalyzed alkylation reaction compared to the usual Trost's ligand. One reason of this huge decrease in enantioselectivity is probably the formation of $\mathrm{P}-\mathrm{N}$ complexes instead of the usual P-P or even P-O $\pi$-allyl complexes.

\section{Experimental Section}

General Procedures. Melting points were determined with a hot-stage microscope. Solvents were purified by standard methods and dried if necessary. Reactions involving palladium catalysis were carried out in Schlenk tube under an inert atmosphere. Tetrahydrofuran was distilled from sodium/benzophenone. Melting points (uncorrected) were determined with a capillary melting point apparatus Büchi SMP-20. Optical rotations were recorded using a PerkinElmer 241 polarimeter. Thin-layer chromatography was performed using Merck silica gel $60 \mathrm{~F}_{254}$ precoated aluminium plates, $0.2 \mathrm{~mm}$ thickness. Column chromatography was performed on silica gel (Merck 60, 70-230 mesh). NMR spectra were recorded on a Bruker $200 \mathrm{MHz}(200.13 \mathrm{MHz}$ for ${ }^{1} \mathrm{H}$, and $81.01 \mathrm{MHz}$ for ${ }^{31} \mathrm{P}$ ) spectrometer.

2-(Diphenylphosphino)nicotinic acid (1). A $0.5 \mathrm{~L}$ three-neck round-bottom flask equipped with a dry ice condenser and a glass-covered magnetic stirbar is charged with anhydrous liquid ammonia $(150 \mathrm{~mL})$. Then sodium $(1.0 \mathrm{~g}, 44 \mathrm{mmole})$ is added to the stirred ammonia solution, followed by the addition of $\mathrm{PPh}_{3}(5.25 \mathrm{~g}, 0.02 \mathrm{~mole})$ in small portions over $30 \mathrm{~min}$. After $3 \mathrm{~h}$, to the red-orange solution of $\mathrm{NaPPh}_{2}$ is added 2-chloronicotinic acid (3.15 g, 0.02 mole) in small portions over a $30 \mathrm{~min}$, followed by the addition of of anhydrous $\mathrm{Et}_{2} \mathrm{O}(100 \mathrm{~mL})$. The reaction 
mixture is allowed to warm to room temp. under argon. The residue is dissolved in water $(150 \mathrm{~mL})$ and extracted with of $\mathrm{Et}_{2} \mathrm{O}(100 \mathrm{~mL})$. The aqueous phase is then filtered and acidified to $\mathrm{p}_{\mathrm{H}}$ 5-6 with concentrated $\mathrm{HCl}$. Filtration of the precipitate and recrystallization from methanol afforded carboxylic phosphine 1 as a pale yellow solid (3.9 g, 64\% yield). Mp 168-171 ${ }^{\circ} \mathrm{C}$ (litt. $\left.165{ }^{\circ} \mathrm{C}\right) ;{ }^{15}{ }^{1} \mathrm{H}-\mathrm{NMR}\left(200 \mathrm{MHz}, \mathrm{CDCl}_{3}\right) \delta$ 7.30-7.45 $\left(\mathrm{C}_{6} \mathrm{H}_{5}, \mathrm{~m}, 10 \mathrm{H}\right), 7.86(=\mathrm{CH}, \mathrm{m}, 2 \mathrm{H}), 7.94$ $(=\mathrm{CH}, \mathrm{m}, 1 \mathrm{H}), 8.13(\mathrm{OH}, \mathrm{s}, 1 \mathrm{H}) ;{ }^{31} \mathrm{P}-\mathrm{NMR}\left(81 \mathrm{MHz}, \mathrm{CDCl}_{3}\right) \delta+2.6(\mathrm{~s})$. Anal. calcd. for $\mathrm{C}_{18} \mathrm{H}_{14} \mathrm{NO}_{2} \mathrm{P}: \mathrm{C}, 70.36$; H, 4.56; P, 10.08. Found: C, 69,87; H, 4.34; P 9.56.

3-(Diphenylphosphino)quinoxaline-2-carboxylic acid (2). The same procedure starting from 3-chloroquinoxaline-2-carboxylic acid (1 g, 4.8 mmole) afforded the carboxylic phosphine 2 as an orange solid (650 mg, 38\% yield). Mp 174-176 ${ }^{\circ} \mathrm{C}(\mathrm{dec}) ;{ }^{1} \mathrm{H}-\mathrm{NMR}\left(200 \mathrm{MHz}, \mathrm{CDCl}_{3}\right) \delta 7.28$ $7.43\left(\mathrm{C}_{6} \mathrm{H}_{5}+=\mathrm{CH}, \mathrm{m}, 11 \mathrm{H}\right), 8.22(=\mathrm{CH}, \mathrm{m}, 1 \mathrm{H}), 8.70(=\mathrm{CH}, \mathrm{m}, 1 \mathrm{H}), 9.44(\mathrm{OH}, \mathrm{s}, 1 \mathrm{H}) ;{ }^{31} \mathrm{P}-$ NMR (81 MHz, $\left.\mathrm{CDCl}_{3}\right) \delta+2.0$ (s). Anal. calcd. for $\mathrm{C}_{21} \mathrm{H}_{15} \mathrm{~N}_{2} \mathrm{O}_{2} \mathrm{P}: \mathrm{C}, 70.39 ; \mathrm{H}, 4.22 ; \mathrm{P}, 8.64$. Found: C, 70.12; H, 4.01; P, 8. 34.

\section{General procedure for synthesis of the diphosphines}

To a magnetically stirred solution of the phosphinocarboxylic acid 1 or 2 (0.4 mmol) in THF $(2 \mathrm{~mL}$ ) was added DMAP ( $3 \mathrm{mg}, 24 \mu \mathrm{mol})$, followed by DCC (90 mg, $0.43 \mathrm{mmol})$. A solution of $(1 R, 2 R)$-1,2-diaminocyclohexane (3) $(23 \mathrm{mg}, 0.2 \mathrm{mmol})$ in THF (1 mL) was then slowly added. After being stirred until all the phosphinoacid has dissapeared (vizualeted by chromatography), the solution was evaporated to dryness. Flash column chromatography of the residue on silica gel using ethyl acetate/petroleum ether (3:1) as the eluent afforded the corresponding diphosphine. $(R, R)-4$ or $(R, R)-5$.

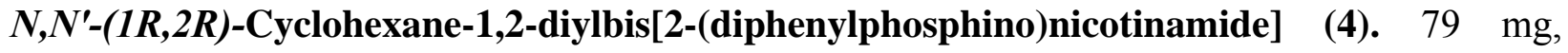
$57 \%$; mp 175-178 ${ }^{\circ} \mathrm{C} ; R_{\mathrm{f}}=0.6$ (ethyl acetate/petroleum ether $(3 / 1) ;[\alpha]_{\mathrm{D}}{ }^{20}=52.2\left(\mathrm{c} 1, \mathrm{CH}_{2} \mathrm{Cl}_{2}\right)$; ${ }^{1} \mathrm{H}-\mathrm{NMR}\left(200 \mathrm{MHz}, \mathrm{CDCl}_{3}\right) \delta$ 1.0-1.4 $\left(\mathrm{CH}_{2}, \mathrm{~m}, 4 \mathrm{H}\right), 1.5-2.0\left(\mathrm{CH}_{2}, \mathrm{~m}, 4 \mathrm{H}\right), 3.76(\mathrm{CHN}, \mathrm{m}, 2 \mathrm{H})$, 6.85-7.0 (CH, m, 6H), 7.0-7.1 (CH, m, 4H), 7.15-7.35 $\left(\mathrm{C}_{6} \mathrm{H}_{5}, \mathrm{~m}, 20 \mathrm{H}\right), 7.65-7.80(\mathrm{CH}, \mathrm{m}, 6 \mathrm{H})$, 8.00-8.20 (CH, m, 4H); ${ }^{31} \mathrm{P}-\mathrm{NMR}\left(81 \mathrm{MHz}, \mathrm{CDCl}_{3}\right) \delta-2.3$ (s); Exact mass (EI) Calcd. for $\mathrm{C}_{42} \mathrm{H}_{39} \mathrm{~N}_{4} \mathrm{O}_{2} \mathrm{P}_{2}$ : 693.2549. Found: 693.2548.

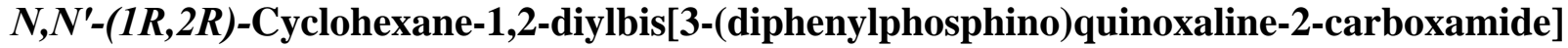

(5). $55.6 \mathrm{mg}, 35 \%$; mp $254-256{ }^{\circ} \mathrm{C}$; Rf $=0.4$ (ethyl acetate/petroleum ether $(3 / 1) ;[\alpha]_{\mathrm{D}}{ }^{20}=-289(\mathrm{c}$ 0.8, $\left.\mathrm{CH}_{2} \mathrm{Cl}_{2}\right)$; ${ }^{1} \mathrm{H}-\mathrm{NMR}\left(200 \mathrm{MHz}, \mathrm{CDCl}_{3}\right) \delta$ 1.0-1.4 $\left(\mathrm{CH}_{2}, \mathrm{~m}, 4 \mathrm{H}\right), 1.5-2.0\left(\mathrm{CH}_{2}, \mathrm{~m}, 4 \mathrm{H}\right), 4.00$ $(\mathrm{CHN}, \mathrm{m}, 2 \mathrm{H}), 6.50\left(\mathrm{NH}, \mathrm{d},{ }^{3} \mathrm{~J}=6.2 \mathrm{~Hz}, 2 \mathrm{H}\right), 7.06\left(\mathrm{CH}, \mathrm{dd},{ }^{3} \mathrm{~J}=7.8 \mathrm{~Hz},{ }^{3} \mathrm{~J}=6.5 \mathrm{~Hz}, 2 \mathrm{H}\right), 7.2-$ $7.4\left(\mathrm{C}_{6} \mathrm{H}_{5}, \mathrm{~m}, 20 \mathrm{H}\right), 7.32(\mathrm{CH}, \mathrm{m}, 2 \mathrm{H}), 8.61\left(\mathrm{CH}, \mathrm{dd},{ }^{3} J=4.5 \mathrm{~Hz},{ }^{4} \mathrm{~J}=1.5 \mathrm{~Hz}, 2 \mathrm{H}\right) ;{ }^{31} \mathrm{P}-\mathrm{NMR}$ $\left(81 \mathrm{MHz}, \mathrm{CDCl}_{3}\right) \delta+1.7$ (s); Exact mass (EI) Calcd. for $\mathrm{C}_{48} \mathrm{H}_{41} \mathrm{~N}_{6} \mathrm{O}_{2} \mathrm{P}_{2}$ : 795.2772. Found: 795.2766 .

Standard alkylation reaction. In a Schlenk tube, $\left[\mathrm{Pd}\left(\eta^{3}-\mathrm{C}_{3} \mathrm{H}_{5}\right) \mathrm{Cl}\right]_{2}(3.65 \mathrm{mg}, 10 \mu \mathrm{mol})$ and the ligand $(40 \mu \mathrm{mol})$ were dissolved in THF $(4 \mathrm{~mL})$. After stirring the mixture for $30 \mathrm{~min}$ at $\mathrm{rt}$, a solution of the racemic acetate $(0.5 \mathrm{mmol})$ in THF $(, \mathrm{mL})$ was added. After $30 \mathrm{~min}$, this solution was transferred to a Schlenk tube containing the nucleophile $(1.5 \mathrm{mmol})$, and $\mathrm{NaH}(1.5 \mathrm{mmol})$, 
or $N, O$-BSA $(1.5 \mathrm{mmol})$ with KOAc $(1 \mu \mathrm{mol})$ in THF $(3 \mathrm{~mL})$. The reaction mixture was stirred at $\mathrm{rt}$ for $24 \mathrm{~h}$. The conversion was determined by GC analysis. The mixture was then diluted with diethyl ether $(5 \mathrm{~mL})$, and water $(5 \mathrm{~mL})$. The organic phase was washed with brine and dried over $\mathrm{MgSO}_{4}$. Evaporation of the solvent gave a residue that was subjected to column chromatography on silica gel. The enantiomeric excess was determined by HPLC, NMR, or measure of the rotation. The separation of the racemic mixture under HPLC conditions is as follows: dimethyl [(E)-1,3-diphenyl-prop-2-en-1)yl]malonate (6a), Daicel Chiralpalk AD, hexane/2-PrOH 6:4; dimethyl [(E)-1-n-propylhex-2-en-1)yl]malonate (6b), Daicel Chiralpalk AD, hexane/2-PrOH 150:1. The separation of the racemic mixture of dimethyl cyclohex-2-en-1-ylmalonate (7) was performed by ${ }^{1} \mathrm{H}$ NMR using $\mathrm{Eu}(\mathrm{hfc})_{3}$ in $\mathrm{C}_{6} \mathrm{D}_{6}$. The enantiomeric excess of compound 8 was determined from the rotation of the pure compound. ${ }^{7}$

\section{Acknowledgements}

A. K. and A. I. thank the CNRS and OTAN for fellowships.

\section{References}

1. Helmchen, G.; Pfaltz, A. Acc. Chem. Res. 2000, 33, 336.

2. Trost, B. M.; van Vranken, D. L. Chem. Rev. 1996, 96, 395.

3. Trost, B. M. Chem. Pharm. Bull. 2002, 50, 1.

4. Hayashi, T. In Catalytic Asymmetric Synthesis, Ojima, I., Ed.; VCH Publishers Inc.: New York, 1993.

5. Pfaltz, A.; Lautens, M. In Comprehensive Asymmetric Catalysis, Jacobsen, E. N.; Pfaltz, A.; Yamamoto, H., Eds; Springer: Berlin; 1999, Vol. II; p 833.

6. Trost, B. M.; van Vranken, D. L.; Bingel, C. J. Am. Chem. Soc. 1992, 114, 9327.

7. Trost, B. M.; Bunt, R. C. J. Am. Chem. Soc. 1994, 116, 4089.

8. Trost, B. M.; Jiang, C. J. Am. Chem. Soc. 2001, 123, 12907.

9. Trost, B. M.; Lee, C. B. J. Am. Chem. Soc. 2001, 123, 3671.

10. Trost, B. M.; Sacchi, K. L.; Schroeder, G. M.; Asakawa, N. Org. Lett. 2002, 4, 3427.

11. Trost, B. M.; Bunt, R. C. J. Am. Chem. Soc. 1994, 116, 9.

12. Lloyd-Jones, G. C.; Stephen, S. C. Chem. Commun. 1998, 2321.

13. Butts, C. P.; Crosby, J.; Lloyd-Jones, G. C.; Stephen, S. C. Chem. Commun. 1999, 1707.

14. Fairlamb, I. J. S.; Lloyd-Jones, G. C. Chem. Commun. 2000, 2447.

15. Ecke, A.; Keim, W.; Bonnet, M. C.; Tkatchenko, I.; Dahan, F. Organometallics 1995, 14, 5302. 